\title{
Unaccompanied Migrant Children's Rights: A Prerequisite for the 2030 Agenda's Sustainable Development Goals in Spain and Sweden
}

\author{
Guadalupe Francia ${ }^{1, *}$, Adrián Neubauer ${ }^{2}(1)$ and Silvia Edling ${ }^{1}$ \\ 1 Faculty of Education and Business Studies, University of Gävle, 80176 Gävle, Sweden; silvia.edling@hig.se \\ 2 Department of Pedagogy, Universidad Autónoma de Madrid, 28049 Madrid, Spain; adrian.neubauer@uam.es \\ * Correspondence: guadalupe.francia@hig.se
}

check for

updates

Citation: Francia, Guadalupe, Adrián Neubauer, and Silvia Edling. 2021. Unaccompanied Migrant

Children's Rights: A Prerequisite for the 2030 Agenda's Sustainable Development Goals in Spain and Sweden. Social Sciences 10: 185. https://doi.org/10.3390/ socsci10060185

Academic Editor: Nigel Parton

Received: 29 January 2021

Accepted: 13 May 2021

Published: 21 May 2021

Publisher's Note: MDPI stays neutral with regard to jurisdictional claims in published maps and institutional affiliations.

Copyright: (c) 2021 by the authors. Licensee MDPI, Basel, Switzerland. This article is an open access article distributed under the terms and conditions of the Creative Commons Attribution (CC BY) license (https:// creativecommons.org/licenses/by/ $4.0 /)$.

\begin{abstract}
Starting from a child rights-based approach to sustainable development, this contribution underlines and compares the discourses in selected Spanish and Swedish migration and education policies on the rights of unaccompanied minors to education and discusses their impact on the enactment of the 2030 Agenda's Sustainable Development Goals in both countries. Based on critical discourse analysis, this research shows the co-existence of two different discourses: one on unaccompanied minors as global rights holders and the other on unaccompanied minors as foreign citizens. By describing unaccompanied migrant minors as citizens rather than children, international migration agreements make it possible for the Spanish and Swedish governments to deprioritize other international agreements on refugees' rights, such as the Convention on the Rights of the Child and the 2030 Agenda. Furthermore, as child rights and sustainable development are mutually reinforcing, the negotiation of rights shows that there are obstacles to accomplishing rights-based Sustainable Development Goal 4 in the 2030 Agenda.
\end{abstract}

Keywords: child rights; Sustainable Development Goals; unaccompanied migrant minors; migrant children

\section{Introduction}

A child rights-based approach to sustainable development can strengthen the implementation of the 2030 Agenda in different areas and at different levels. Integrating the Convention on the Rights of the Child (CRC) in the 2030 Agenda's goals and targets can be a way of mobilizing people to identify and enact practices and measures for sustainable development and in relation to children's rights (OHCHR United Nations Human Rights Office of the Rights Commissioner 2020). Furthermore, fulfilling the rights of the most vulnerable children's groups is a priority task in order to ensure that the 2030 Agenda's goals and targets are met (OHCHR United Nations Human Rights Office of the Rights Commissioner 2020).

Securing the rights of the most vulnerable children is particularly relevant for the accomplishment of Sustainable Development Goal 4 (SDG4) of the 2030 Agenda, which aims to "ensure inclusive and equitable quality education and promote lifelong learning opportunities for all" (UNESCO 2019a). Considered as a fundamental right in the CRC, the right to education is also a powerful tool for sustainable development in the 2030 Agenda (UNESCO 2019b). UNICEF (2007) specifies a human rights approach to development, in which the right of education is regarded as fundamental and requires educational environments that offer equal opportunities, no discrimination of any kind, freedom from all forms of violence, and respect for children's and young people's language, cultural, and religious backgrounds.

Even though both the CRC and the 2030 Agenda guarantee the rights of all children to education, one child group that is at risk of being left behind is that of unaccompanied 
migrant minors seeking asylum in Europe (European Council on Refugees and Exiles [ECRE] 2018).

In the peak migration year of 2015 and the displacement of some 92,000 unaccompanied minors (Eurostat 2020a) there was an overrepresentation of males aged 16-17 years (European Migration Network 2018; European Council on Refugees and Exiles [ECRE] 2018; Eurostat 2020a; Save the Children 2018, 2019). Even if the number of unaccompanied minors has since decreased to 13,795 , there is still an overrepresentation of males and youths. In $2019,85 \%$ of the unaccompanied minors were males and two-thirds were aged between 16 and 17 years, 22\% were aged between 14 and 15 years, and only $11 \%$ were under the age of 14 years. Moreover, the majority of unaccompanied minors coming to the European Union were from Afghanistan (30\%), Syria (10\%), Pakistan (10\%), Somalia (5\%), Guinea (5\%), and Iraq (5\%) (Eurostat 2020a).

At the same time, different political actors made use of the fact that the majority of unaccompanied minors were males aged between 16 and 17 years as an argument to disqualify their rights to housing, education, safety, and asylum. Unaccompanied minors are at times described as "threats" that should be deported. Cuts in welfare services and child protection systems, together with political decisions to dismantle asylum systems, have also contributed to the negation of the rights of unaccompanied migrant children in Europe (European Council on Refugees and Exiles [ECRE] 2018).

In line with the OHCHR United Nations Human Rights Office of the Rights Commissioner (2020), the fulfilling of the rights of unaccompanied migrant minors is seen as a necessary condition for achieving the 2030 Agenda's goals and targets. In order to enhance knowledge about the possibilities and obstacles for promoting the rights of this particular group, the aim of this article is to highlight and compare the discourses identified in selected Spanish and Swedish migration and education policies on unaccompanied migrant minors' rights to education and to discuss the impact of these discourses on the enactment of the 2030 Agenda Sustainable Development Goals in both of these countries.

The article begins by presenting the research aims, theoretical starting point, and earlier research. This is followed by a presentation of the research methods and materials and an introduction to the Spanish and the Swedish cases. The comparative results analysis is then presented. Finally, the article discusses the impact of the different discourses in the Swedish and Spanish policy documents on unaccompanied minors from a child rights perspective and relates them to both the CRC and the 2030 Agenda.

\subsection{The Dilemma between National State Sovereignty and Human Rights}

Taking Benhabib (2004a) article as a theoretical starting point, we argue that the current restrictive European migration policies highlight the existing dilemma between the rights of European democracies to regulate their state territories and refugees' rights to full membership, a democratic voice, and territorial residence. According to Benhabib (2004b, p. 196), migration and citizenship policy relating to migrants in a nation often creates distinctions between "us" " ... who belong to the sovereign people ..." and "the others" who do not belong. Based on sovereignty principles, such polices often compete and conflict with human rights legislation, thereby highlighting the challenges that globalization imposes on national states. This is often reflected in the arguments used by member states to design and implement measures that violate the human rights of migrants in order to safeguard national security (Fernández Peláez 2018). The same argument has been used repeatedly to implement mobility restrictions for immigrants. This phenomenon occurred in the European Union as a result of the terrorist attacks in Paris in 2015, after which France, Norway, Sweden, Denmark, Germany, and Austria established border controls aimed at the immigrant population in the Schengen Area due to fears of further attacks (Morgades Gil 2019). In fact, in France these controls have been in force since 2015 (Morgades Gil 2019). Exceptionality and the deprivation of rights have become normal in terms of citizen security. 
As a consequence, Europe's moral and political principles for human rights risk being renegotiated in relation to its geographical boundaries. Therefore, the moral conscience and political reflectivity of liberal European democracies have led to their treatment of refugees, foreign guest workers, and asylum seekers as "the others." The way that these liberal democracies redefine the rights of "these others" shows how they deal with the dilemma between the universal respect for human rights and national state sovereignty (Benhabib 2004b).

Starting from the CRC conception that all children on the move are rights holders, this article makes no distinction between different categories of unaccompanied minors migrating across borders or being forcibly displaced (see UNICEF 2018, 2021). Here, unaccompanied minors are children migrating alone for different reasons and with different juridical status. In this article, the term unaccompanied minors encompasses asylum seekers, refugees, economic migrants, and migrant children who have emigrated alone to Spain and Sweden, and is used in order to avoid a reductionist and exclusively legal vision of this group in all socio-educational fields.

\subsection{The Limitations of the CRC to Protect Migrant Children's Rights}

Even if the fulfillment of the CRC is a necessary condition for the enactment of the 2030 Agenda at the national level (OHCHR United Nations Human Rights Office of the Rights Commissioner 2020), its limitations as legal text could make a child rights-based approach to sustainable development difficult. For instance, earlier research has shown that several CRC rights are difficult to interpret at the national level because their formulations are ambiguous, diffuse and mean different things in different contexts (Ahrnér 2006; Schiratzki 2013).

At the same time, the CRC cannot always be implemented strictly in all national contexts because it includes the so-called second-generation human rights that require active action on the part of the state to guarantee their implementation. These rights are social, economic, and cultural rights, such as education, care, and health. Unlike first-generation rights (also called freedom or civic and political rights) that aim to protect individuals from state interference, second-generation human rights require the state to allocate public resources that are not always possible to offer (Willems and Vernimmen 2017).

Furthermore, earlier research has also pointed out that the CRC does not automatically ensure the rights of migrant children when restrictive migration policies are in place (Schiratzki 2013). Even when the CRC is incorporated in national legislation, it is likely to have less value than other national laws (Schiratzki 2013; Thorburn Stern 2018, 2019a, $2019 b)$. One reason why the CRC does not protect this group is because migrant minors tend to be considered and treated primarily as migrants and secondly as children, particularly in national contexts where migration is regarded as a threat (Thorburn Stern 2018, 2019a, 2019b; Zillen 2019; Lainpelto 2019; Francia and Edling 2020).

\section{Methods and Material}

This article is based on a comparative research design of Spanish and Swedish policy discourses concerning unaccompanied migrant minors and their right to education in Spain and Sweden.

\subsection{The Comparative Research Design}

Based on Bray and Thomas' comparative multidimensional design (Bray et al. 2007), this research includes the following analytical dimensions:

- The geographical dimension:

The comparison unit used in this dimension is the national level in the two selected countries of Spain and Sweden. These countries were chosen because they are EU countries that have signed both the CRC and the 2030 Agenda and have received a considerable number of unaccompanied migrant minors in recent years.

- The non-geographical demographic dimension 
The comparison unit used in this dimension is unaccompanied migrant minors from Morocco in Spain and from Afghanistan in Sweden. These groups were selected for each country because they constitute the majority of unaccompanied minors living in the respective countries. Another reason for this selection is the bilateral agreements signed by Sweden with Afghanistan and Spain with Morocco concerning the deportation of unaccompanied minors.

- The aspects of education and society

The comparison units used in this dimension are the discourses found in the two countries' migration and education policy documents concerning unaccompanied Moroccan and Afghan migrant minors. The selected data include policy documents at the supranational and national levels.

\subsection{Reading Policy from a Critical Discourse Analysis Perspective}

Starting from the assumption that all discourses are historical and contextual, Critical Discourse Analysis (CDA) research claims to analyze those that pay attention to the mediation between discourses and their social contexts (Meyer 2003). CDA is based on an "... analysis of the dialectal relationships between semiosis (including language) and other elements of social practices" (Fairclough 2003, p. 123).

Following Fairclough (2000), the interpretation of the empirical data encompasses three dimensions: (a) text analysis (description), (b) processing analysis (interpretation), and (c) social analysis (explanation). In our study, these dimensions correspond to our three research questions:

(a) Which discourses on unaccompanied migrant minors and their rights to education are present in the Spanish and Swedish migration and education policies? (description)

(b) Which intertexts are presented/referred in the selected policies? (interpretation)

(c) How can these discourses be explained in a wider discussion about the enactment of the CRC/2030 Agenda? (explanation)

Based on the definition of intertexts as texts that are necessary to include in the analysis in order to understand the discourse on unaccompanied minors and their rights in the Spanish and Swedish migration and education policies (see Riffaterre 1990), this CDA analysis includes the following intertexts (Table 1): 
Table 1. Supranational and national policies which regulate the rights of unaccompanied children in Spain and Sweden.

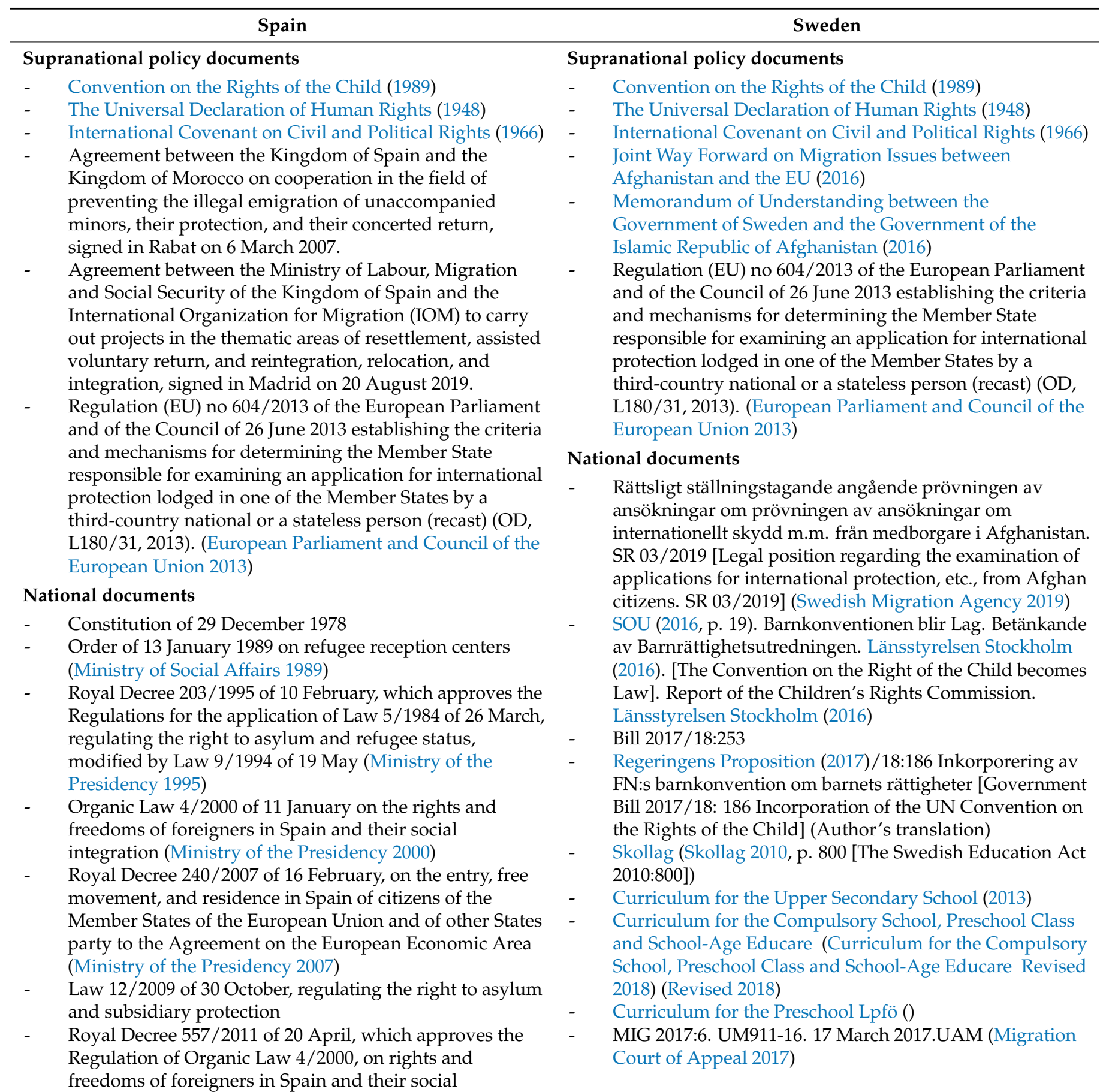

freedoms of foreigners in Spain and their social integration, after its reform by Organic Law 2/2009 (Head of State 2009)

Note. Own elaboration. Level $\mathrm{b}$ (interpretation) in the project focused on identifying which text were referred to or/and quoted in the migration and education policies. The analysis of level 2 aimed to identify how these intertexts are used in the argumentation for these policies.

\section{The Spanish Case}

This section provides information about the situation of the selected unaccompanied migrant children, their rights to education, and migration policies relating to this group in Spain. 


\subsection{Unaccompanied Minors in Spain}

In the last 30 years Europe has faced a new socio-political phenomenon: unaccompanied migrant minors (Cónsola Párraga 2016; Figueredo Canosa et al. 2017; Flores González 2018; Fernández-Ramos 2019). In the 1990s these children started to emigrate to Spain, especially Andalucía and Islas Canarias (Alemán Bracho 2011; Cónsola Párraga 2016; Jiménez Álvarez 2019).

With regard to the actual number of unaccompanied migrant children in Spain, it is important to stress that providing exact data is problematical. This could be a consequence of their high mobility inside the country or their attempts to migrate to other European countries (Mendoza and Belarra 2017). In 2019, the Minister of the Interior concluded that Spain was recorded as having 12,301 unaccompanied migrant children (Accem 2019), but that this number was not reliable (Horcas López 2016; Jiménez Álvarez 2019) because many of these minors steer clear of the authorities, which means that they are outside the child protection system and unable to formally request nationality or asylum protection.

There are also asylum seekers who try to enter Spain through legal channels. In 2014 and 2015 the number was relatively small (1300 and 2420, respectively), but in 2016 the trend changed (Eurostat 2020b). Suddenly, the number increased to 19,635, a figure similar to that for 2017 (Eurostat 2020b). Likewise, in 2019 Spain received the highest number of asylum seekers: 25,160 (Eurostat 2020b). However, in relation to unaccompanied migrant minors the number of asylum seekers is much lower. For example, from 2014 to 2019 Spain received 265 asylum applications from this collective (Eurostat 2020b).

Most of the unaccompanied children in Spain are boys between the ages of 15 and 17 (Cónsola Párraga 2016; Flores González 2018; Jiménez Álvarez 2019). Research has shown that most of these children come from Morocco and Algeria (Angelidou and AguadedRamírez 2016; Aguaded-Ramírez and Angelidou 2017; Jiménez Álvarez 2019) due to their geographical proximity to Spain (Flores González 2018; Fernández-Ramos 2019). The majority want to improve their lives and leave their country for this reason. However, when they get into the social care system they feel disappointed because it does not meet their expectations of getting a good job and earning a lot of money (PUCAFREU 2013). Their expectations are often unrealistic, given that Europe and Spain are not the idyllic places they are made out to be by the media, social networks, and those who emigrated before them (Bueno Abad and Luján 2006). As a result, many are not interested in getting into the social care system and instead turn to illegal activities in order to survive (PUCAFREU 2013). At the same time, social service centers need to be improved in terms of habitability (Mendoza and Belarra 2017; Andrés Laso 2020), staff training (Sánchez-Fernández et al. 2017), privacy, and access to legal defense, health, and hygiene (Solanes Corella 2016).

In Spain the protection of these children comes under the autonomous communities (López Martín et al. 2016; Mendoza and Belarra 2017). Some autonomous communities (Andalucía, Catalunya, Comunidad Valenciana, Madrid and Euskadi) focus on these children in their social service systems, which depletes their already insufficient resources (Vinaixa i Miquel 2019). These autonomous communities receive more unaccompanied migrant children due to being close to the frontier with Andalucía and because they are represented in social media as regions with great opportunities (Catalunya, Comunidad Valenciana, Madrid and Euskadi) (Cónsola Párraga 2016).

\subsection{Migrant Pupils' Rights to and within Education in Spain}

Unaccompanied migrant children's rights to education in Spain are framed by supranational and international documents signed by the country. At national level, the Constitution of 29 December 1978 states that basic education is free and compulsory for everyone (Art. 27) (General Courts 1978). In addition, the Order of 13 January 1989 (Ministry of Social Affairs 1989) relating to refugee reception centers guarantees the equity of rights for the refugee population to access the Spanish social services, including education and culture. Nevertheless, the document affirms that this will only be possible when the state has sufficient resources. Also, refugees have to justify their incapability of accessing basic 
needs. On the other hand, reception centers are responsible for offering activities that promote the Spanish culture and language. Further, in its 15th Article, the Royal Decree 203/1995 (Ministry of the Presidency 1995) guarantees the rights of the refugee population, and especially unaccompanied migrant minors, to access social support.

The next legal reference, the Organic Law 4/2000 (Ministry of the Presidency 2000), commits to integrating the immigrant population and promoting their participation in cultural, economic, social, and political life. Education plays a fundamental role here in helping migrant children to learn the Spanish language and European Union values and to have their human rights met. Likewise, the 9th Article refers explicitly to the right to education for foreigners under the age of 16 years and to the requirement that public Administration should offer lessons that promote the social integration of migrant children. In the same way, the Royal Decree 240/2007 (Ministry of the Presidency 2007), Law 12/2009 (Head of State 2009) and the Royal Decree 557/2011 (Ministry of the Presidency 2011) strengthen the legal framework for guaranteeing the right to education for the immigrant and refugee population in Spain.

\subsection{Restrictive Migration Policies and an Anti-Migration Discourse}

Organic Law 4/2000 (Ministry of the Presidency 2000) stipulates that every immigrant person who wants to apply for Spanish citizenship must not have committed any criminal offense (Art. 31). In relation to this, Article 57 states that any immigrant person who has been found guilty of an offense and served a sentence of more than one year should be expelled. García España (2017) criticizes the Spanish penal code because it does not give these children a second chance and the only solution for such cases is expulsion. On the other hand, even if an unaccompanied migrant child is granted Spanish citizenship, they can be returned to their country of origin if the Administration considers this to be the best course of action (Art. 35). In the cases of unaccompanied migrant children who are in the social protection system and are able to apply for Spanish citizenship when they reach adulthood, their applications will depend on the Administration's report of their conduct (Art. 35).

The Agreement between the Kingdom of Spain and the Kingdom of Morocco, signed in Rabat on 6 March 2007, relates to cooperation in preventing the illegal emigration of unaccompanied minors, their protection, and their concerted return (Agreement between the Kingdom of Spain and the Kingdom of Morocco 2007). Both countries agreed to prevent the migration of these children and to facilitate their return to their families (Art. 2). In Article 7, Spain promises to finance their return and prevention programs. Spain also signed the Agreement between the Ministry of Labour, Migration and Social Security of the Kingdom of Spain and the International Organization for Migration (IOM) in Madrid on 20 August 2019 in order to carry out projects in the thematic areas of resettlement, assisted voluntary return, reintegration, relocation, and integration (Agreement between the Ministry of Labour 2019). Under this agreement Spain finances four immigration programs, three of which are related to resettlement and assisted voluntary return. Spain invests more than EUR 3.5 million in them, but only EUR 300,000 in integration programs.

Spain engages in two practices that are questioned by some researchers (Solanes Corella 2016; Fernández Peláez 2018; Fernández-Ramos 2019). The first is when an unaccompanied migrant child is identified by Spanish authorities and has to have his or her age determined. According to international rights, authorities have to use the documentation offered by the children to prove their ages. The problem is that unaccompanied children do not always carry such documentation (Aguaded-Ramírez and Angelidou 2017), which means that the Spanish authorities try to determine their ages using medical testing, the most common of which is radiography of the wrist. This is not a very reliable practice (Fernández-Ramos 2019), especially if it takes place in a concrete private clinic where all the tests concluded that patients were adults (Fernández Peláez 2018). As a result, if the authorities stipulate that someone is not a child, he or she cannot enter the social care 
system. For that reason, Prada Belver et al. (2013) considered it necessary to take at least three different radiological tests to determine the child's bone maturation.

The second criticized practice is what is known as the "warm return." This is when a state identifies a migrant person illegally crossing its border and returns that person directly to their country of origin without a judicial process. Solanes Corella (2016) denounced this situation at the border between Spain and Morocco as it is a violation of human rights, especially in the case of children. This practice contradicts human rights because everyone has the right to enjoy a fair legal process (The Universal Declaration of Human Rights 1948, Art. 10). This fact is vital in the case of children because one of the guiding principles for expelling them from the host country should be to ensure, whenever possible, their family reunification in the country of origin (Convention on the Rights of the Child 1989, Art. 10).

In the social imaginary, this group of minors is associated with violence and delinquency, being more accentuated in Moroccan children (Mendoza and Belarra 2017; Barba del Horno 2019). This view has been promoted by social media as a very negative image. Some news sources also talk about the collapse of the social services and reception centers (Mendoza and Belarra 2017). Information like this has been used by the new far right to consolidate its position in public institutions. The main political party representing this ideology is Vox, which obtained 52 of the 350 seats in the National Congress. Its main support was in autonomous communities (Andalucía, Madrid and Murcia) and cities (Ceuta) in which this phenomenon is at the center of the socio-political debate, especially in Ceuta. The main points of its ideology are authoritarianism, nativism, and cultural homogeneity, with a strong position against illegal migration (Ferreira 2019). Although there are movements and institutions that defend the rights of these minors (APDHA, Fundación Raíces, Harraga, Plataforma de Infancia, local manifestations), there are also movements against the integration of these children into Spanish society (Hortaleza se defiende, Social Home, local manifestations).

\section{The Swedish Case}

This section provides information about the situation of the selected unaccompanied migrant minors, their rights to education, and migration policies relating to this group in Sweden.

\subsection{Unaccompanied Minors in Sweden}

Afghan minors were overrepresented as asylum applicants in Sweden during the period 2015-2017 (Migrationsinfo.se 2018). The majority of Afghan minors are Hazaras and Shiites, both of which are exposed minority groups in Afghanistan at risk of being discriminated against and harmed (Swedish Migration Agency 2019).

Compared to other countries in the European Union, Sweden received the highest number of asylum seekers in 2015 in relation to its population. In 2015, 162,877 people sought asylum in Sweden, and of these 35,369 were unaccompanied minors (Migrationsinfo.se 2018). In the wake of the massive influx of migrants in 2015 several European countries chose to deal with the tense situation by closing their borders and introducing stricter asylum and migration policies in 2016. In attempts to find ways of stemming the flow of migrants entering Europe, deals were made with countries like Libya, Egypt, Sudan, Turkey, and Nigeria to prevent people crossing the borders to Europe. The restrictive policies that were introduced seriously affected the situation of migrants (Open Society Foundation 2016). Like many other countries, Sweden introduced a more restrictive migration legislation by making it more difficult for asylum seekers to receive residence permits and be reunited with their families (see Lag 2016, p. 752). Since 2016, Sweden has had one of the most restrictive policies regarding migration and asylum-seeking in the European Union (Thorburn Stern 2018).

The asylum process for unaccompanied minors in Sweden involves several interviews with the Swedish Migration Agency and representatives from the municipality in which the unaccompanied minor will live. During these interviews, the children have the right to be 
supported by an interpreter. Unaccompanied minors with special needs, such as disability, also have the right to receive special support during these interviews. After these initial interviews an asylum investigation is initiated based on different interviews in which the minors can be accompanied by a public counselor. During the asylum process minors are obliged to prove their identity and age. According to the Swedish Migration Agency, the best way of proving identity is by means of a passport or identity card. However, since 2017 medical age assessments have been carried out in cases where the migration authorities suspect there is reason to doubt the age of the asylum seekers. The Agency further states that identification of the child's age is particularly important in the asylum process because children seeking asylum have different rights than adult asylum seekers. The Swedish Migration Agency's decision on the asylum application is communicated to the minor in the presence of his or her official guardian. The asylum decision is written in Swedish but is explained to the minors by an interpreter. According to Swedish law, accompanied minors can only be granted asylum in Sweden if they are refugees or in need of subsidiary protection. Only in exceptional circumstances can unaccompanied minors who do not belong to these two categories be granted asylum. According to the Swedish Migration Agency, these cases are rare and reflect special and extremely grave circumstances (Swedish Migration Agency 2021a).

Nowadays, most asylum seekers are granted temporary residence permits. However, minors can apply for an extension to these residence permits. Young people between the ages of 17 and 24 who are studying at upper secondary school can sometimes be granted a longer residence permit to enable them to complete their studies (Swedish Migration Agency 2021a).

An analysis of the work situations of 9975 unaccompanied minors in Sweden between 2003 and 2012 shows that Afghan youth have been more successful in finding work than other unaccompanied minors (Celikaksoy and Wadensjö 2015). However, since 2016 the situation has become more difficult for these and other minors due to Sweden's stricter immigrant policy. In 2017, the majority of suicide cases reported in the group of asylumseeking unaccompanied minors were Afghan boys. They were also overrepresented in their contacts with adolescent outpatient psychiatric care (The National Board of Health and Welfare 2018; The Ombudsman for Children in Sweden 2017a, 2017b; Save the Children 2018, 2019; Nordic Welfare Centre 2020). There were also reports of an alarming number of refugee children and youth going missing in Sweden, with Afghan and Moroccan minors being two of the largest groups (Länsstyrelsen Stockholm 2016). Moreover, the consequence of Sweden's stricter migration policy was that the number of unaccompanied asylum-seeking minors drastically decreased. In 2017, 1336 youth/children sought asylum compared to 2199 in 2016 and 35,369 in 2015 (Migrationsinfo.se 2018).

Paradoxically, at the same time as policies are making life more difficult for unaccompanied minors, this collective is also protected by the CRC (Swedish Migration Agency 2017). Sweden signed the Dublin Convention, thus implying that unaccompanied minors have the right to protection due to their vulnerable position. The Dublin Convention obliges the state to compensate municipalities economically so at they are able to take responsibility for unaccompanied minors, for example, by ensuring their education, finding accommodation, and appointing adult trustees (Swedish Migration Agency 2017; Migrationsinfo.se 2018).

\subsection{Migrant Pupils' Rights to and within Education in Sweden}

Migrant children's rights to education are guaranteed in Sweden by different international agreements and national legislation, such as the Education Act, and educational policy documents like the national curricula for the different school forms. Swedish legislation makes no distinction between the right to education for different groups of children on the move (asylum seekers, refugees, economic migrants, and other migrants).

In Sweden, all unaccompanied minors and young adults have the same right to attend school and preschool as other children and young people living in Sweden. 
The Swedish legislation stipulates that the municipalities in which the unaccompanied minors live are responsible for guaranteeing their right to equitable education (Swedish Migration Agency 2021b).

Furthermore, in 2018 the Swedish coalition government submitted Bill 2017/18:253, which offered unaccompanied minors who had arrived in Sweden prior to 24 November 2015 limited permission to stay in the country if they applied for upper secondary school study programs. This offer was introduced as compensation for the long asylum process they had been subjected to when arriving in Sweden as child migrants (Swedish Migration Agency 2019). However, the bill was seriously questioned by several Swedish authorities because it was considered impossible to implement in practice. The Council on Legislation, the Supreme Administrative Court in Stockholm, the Supreme Administrative Court in Gothenburg, the Swedish Migration Agency, and the Swedish Bar Association were among the critical voices that warned against long waiting times for applications for this limited permission for upper secondary studies (The Council of Legislation 2018; Dagens Juridik 2017). As the critical voices had warned, the waiting time for permission at the Swedish Migration Office proved to be long. In December 2018, 6968 applicants had received notification from the Swedish Migration Office, 4497 of which were approved and 2511 refused (Dagens Nyheter 2018).

\subsection{Restrictive Migration Policies and Anti-Migration Discourses}

In October 2016 the European Commission signed an agreement with the Afghan government entitled A Joint Way Forward on Migration Issues between Afghanistan and the EU (2016) (JWF), which gave legal support to the mass deportation of Afghan refugees at EU level. This agreement also made it possible for EU states to make bilateral agreements with Afghanistan to facilitate mass deportations that could be executed by force, even if the Afghan refugees had already applied for asylum in the EU (Joint Way Forward on Migration Issues between Afghanistan and the EU 2016; Sveriges Television 2016). However, the European Council on Refugees and Exiles [ECRE] (2017) stated that it was necessary to follow the consequences of this political agreement, particularly with regard to the situation of vulnerable groups and Afghan children. The deportation of vulnerable groups was not recommended under any circumstances. One vulnerable group included Afghan citizens who had never lived in the country, or who had not lived there for long periods and lacked family and networks there. In addition, it was stated that all voluntary returns of Afghan citizens should only be implemented " ... on the basis of full information, go-and-see visits and informed consent" (p. 4).

As already indicated, at the beginning of 2016 Sweden decided to follow the EU's restrictive migration policy and temporarily closed its borders. At the same time, Sweden signed the bilateral Memorandum of Understanding between the Government of Sweden and the Government of the Islamic Republic of Afghanistan (2016). This bilateral Memorandum allowed Sweden to return Afghan children and young people to Afghanistan.

In addition, Sweden introduced a general restriction on all asylum seekers being granted residence permits and reunited with their families. Furthermore, in 2016 the Swedish migration authorities introduced a medical age assessment of unaccompanied minors using bone tests or dental X-rays (Migrationsinfo.se 2018), both of which were strongly criticized by medical doctors and the Swedish Pediatric Association as being unreliable (Sveriges Television 2017a, 2017b; Hjern and Ascher 2015).

As a result of this restrictive migration policy, the possibility for Afghan refugees to obtain asylum in Sweden has decreased. Even though in 2017 the number of Afghan citizens amounted to half of all the refugees in Sweden, only 28\% were granted asylum, compared to $91 \%$ of Syrians. This high level of refused asylum requests meant that unaccompanied Afghan minors were highly likely to be deported (The Guardian 2017a, 2017b). Together with Germany, Sweden was at the forefront of these enforced deportations of Afghan citizens in 2017 (The Guardian 2017b). 
In addition, the resurgence of strong radical right-wing parties and movements has challenged the right to apply for asylum and impacted the mainstream parties' policies in relation to the rights of Afghan children and youth to stay in Sweden. Based on a political discourse characterized by ethno-nationalist xenophobia and the return to traditional values, fascism, and nationalism, the radical right wants to see a more restrictive Swedish migration policy. At the same time, the mainstream parties often tend to share the radical right-wing restrictive migration discourse and make political proposals to avoid losing votes to the right-wing nationalist parties (Akkerman 2012; Rydgren 2018a, 2018b; Rydgren and Meiden 2016). Consequently, in the political debate during the parliamentary election campaign in 2018, the radical parties and movements demanded a mass deportation of Afghan minors by arguing that they were both adults and "fake refugees" (see SverigeDemokraterna 2018).

On the other hand, critical opponents of restrictive migration policies in the Swedish media have questioned the legitimacy of the mass deportation of unaccompanied minors. Furthermore, a hard media debate has questioned the effectiveness of the medical age assessment methods used by the Swedish Migration Agency (Hjern and Ascher 2015; The Swedish Paedriatic Society 2017; Sveriges Television 2017a, 2017b).

At the same time, different civil organizations in Sweden started a number of action campaigns against the planned deportations of Afghan citizens to Afghanistan. For instance, the network Nu är det Nog (Enough is Enough) started a campaign together with other civil organizations in an attempt to prevent the Swedish government, Parliament, and the Swedish Migration Agency deporting Afghan citizens to Afghanistan as planned on 10 September 2018 (Nu är det Nog 2018). Despite these different anti-deportation actions, Afghan citizens were again deported to Afghanistan during first week of September 2019 (Aftonbladet 2019).

According to a Save the Children report (2018), the number of children and young people returned to Afghanistan from the EU is unknown. However, Save the Children $(2018,2019)$ pointed out that this involves unaccompanied children, children accompanied by their families, and young people who have recently reached the age of 18 . The former group refers to young people who migrated to EU countries when they were children but, because of lengthy proceedings, reach the age of 18 before any decisions are taken (see Save the Children 2019). Save the Children $(2018,2019)$ reported that children and young people returned to Afghanistan from the EU lack legal, physical, and psychosocial safety and support during the return process. Furthermore, children and young people who were born in Iran and Pakistan are deported to Afghanistan even if they have never set foot there and lack a social network and stable living conditions in that country. Therefore, Save the Children (2018) recommended EU countries to incorporate procedural safeguards that guarantee that any decision about return and the return process pay attention to the best interests of the children according to the UN Convention on the Rights of the Child. Interviews with children and young people who have returned to Afghanistan from Sweden (Save the Children 2019) showed that they were not believed by the Swedish Migration Agency during the migration process and that they had to wait a long time for a final decision. They also expressed that their reasons for staying in Sweden were not correctly investigated.

\section{Results}

This research shows two different discourses on unaccompanied Moroccan minors in Spain and Afghan minors in Sweden in the analyzed legal and political documents. The first discourse relates to the conception of unaccompanied minors as global rights holders, while the second is related to the conception of this same group as foreign citizens. In this section we analyze these two discourses and discuss their implications for the enactment of the CRC and the 2030 Agenda in relation to unaccompanied minors arriving in Spain and Sweden. 


\subsection{Unaccompanied Minors as Global Rights Holders or Foreign Citizens in Spain and Sweden}

\subsubsection{Transnational Policies}

The CRC that Spain and Sweden signed in 1989 considers all children seeking refugee status as global rights holders (Article 22). Phrases that are emphasized in the discourse revolve around links between rights and practices, such as: "appropriate measures to ensure," "in accordance with applicable international or domestic law," "appropriate protection ... in the enjoyment of applicable rights":

States Parties shall take appropriate measures to ensure that a child who is seeking refugee status or who is considered a refugee in accordance with applicable international or domestic law and procedures shall, whether unaccompanied or accompanied by his or her parents or by any other person, receive appropriate protection and humanitarian assistance in the enjoyment of applicable rights set forth in the present Convention and in other international human rights or humanitarian instruments to which the said States are Parties. (Convention on the Rights of the Child 1989, Article 22, page 4, authors' italics)

Based on the discourse of children as global rights holders, the CRC stipulates that all children have the right to be protected by state parties, which are obliged to take all appropriate measures to ensure the enactment of the CRC, regardless of the children's backgrounds, gender, age, or their parents' backgrounds.

States Parties shall respect and ensure the rights set forth in the present Convention to each child within their jurisdiction without discrimination of any kind, irrespective of the child's or his or her parent's or legal guardian's race, colour, sex, language, religion, political or other opinion, national, ethnic or social origin, property, disability, birth or other status. (Convention on the Rights of the Child 1989)

The discourse of children as rights holders is present in the UN's Joint general comment No. 3 (2017) of the Committee on the Protection of the Rights of All Migrant Workers and Members of Their Families, and No. 22 (2017) of the Committee on the Rights of the Child on the general principles regarding the human rights of children in the context of international migration (United Nations 2017). Referring to the nondiscrimination principle of the CRC, these documents claim to treat migrant children first and foremost as children rather than migrants:

... non-discrimination principle of the Convention on the Rights of the Child obliges States parties to respect and ensure the rights set forth in the Convention to all children, whether they are considered, inter alia, migrants in regular or irregular situations, asylum seekers, refugees, stateless and/or victims of trafficking, including in situations of return or deportation to the country of origin, irrespective of the child's or the parents' or legal guardians' nationality, migration status or statelessness. (United Nations 2017, p. 3)

... States should ensure that children in the context of international migration are treated first and foremost as children. States parties to the Convention have a duty to comply with their obligations set out therein to respect, protect and fulfil the rights of children in the context of international migration, regardless of their or their parents' or legal guardians' migration status. (United Nations 2017, p. 3)

\subsubsection{National Policies}

The discourse on children as global rights holders also appears in the Swedish and Spanish legislation in the area of education. For instance, the Swedish Education Act (Skollag 2010, p. 800) guarantees new arrivals the right to and within education by obliging schools to take special pedagogical measures for this group. This legislation also stipulates the responsibility of schools to evaluate as soon as possible the knowledge levels of the 
new arrivals in order to ensure that they receive the necessary pedagogical support and thereby guarantee their right to equitable education.

In Spain, Law 3/2006 stipulates that these children are "students with a specific need for educational support" (Head of State 2009, Title II, Chapter 1), although at the same time they are categorized as "late enrolled students" in the Spanish educational system (Title II, Chapter 1, Section 3). In Articles 78 and 79 the Spanish Administration promises to guarantee their right to education and "develop specific programs for students with serious language or skills deficiencies or basic knowledge, in order to facilitate their integration into the corresponding course" (Head of State 2009, Title II, chp. 1, sec. 3, Art. 79).

At the same time, both countries attribute the responsibility to school leaders to place the pupils in the school year that corresponds to their age. However, in Spain this decision can be motived by personal circumstances, the last academic year completed in the country of origin, and academic performance (Head of State 2009, Title II, chp. 1, sec. 3, Art. 78).

One important difference between these two national legislations is that the Swedish Education Act guarantees the rights of children with a mother tongue other than Swedish to receive pedagogical support in that language-something that Spain omits in its law. Nevertheless, they agree on the importance of offering linguistic courses to develop the host language. All this is regulated by Swedish law as follows:

Study guide in the mother tongue $\S 12 \S$ A newly arrived pupil, who has been received within the school system in the upper secondary school, the compulsory special school or the special school and whose knowledge has been assessed in accordance with $\S 12 \mathrm{c}$, shall receive study guidance in the mother tongue if it is not obviously unnecessary. The study guide should aim at giving the student the conditions to reach the minimum knowledge requirements. (Skollag 2010, p. 800 [The Swedish Education Act], Chapter 3 §12i)

Furthermore, the right to equitable education for all children is guaranteed in both the Swedish and the Spanish education policy documents:

The Education Act stipulates that education in each school form should be equivalent, irrespective of where in the country it is provided. National goals are specified through the norms for equivalence. However, equivalent education does not mean that teaching should be the same everywhere, or that the resources of the school are to be allocated equally. Account should be taken of the varying circumstances, needs and the students' level of knowledge. (Curriculum for the upper secondary school, Sweden)

Equity, which guarantees equal opportunities for the full development of the personality through education, educational inclusion, equal rights and opportunities that help overcome any discrimination and universal accessibility to education, and act as compensatory element of personal, cultural, economic and social inequalities, with special attention to those derived from any type of disability. (Head of State 2009, Preliminary Title, Chapter 1, Art. 1, Spain)

Even though these national policy documents do not explicitly mention unaccompanied minors as rights holders, the studied educational political documents stipulate rights in and within education for all children and young people in Spain and Sweden, irrespective of their place of birth. By using phrases like as "no-one" or "account should be taken of the varying circumstances and needs of pupils," these documents also include unaccompanied minors attending school as rights holders.

On the other hand, in Spain Law 3/2006 does not refer to the CRC explicitly but affirms that the main objective of the Spanish educational system is to:

offer to all students a space for reflection, analysis and study about the characteristics fundamental principles and the functioning of a democratic regime, of the principles and rights established in the Spanish Constitution and in the treaties and universal declarations of human rights, as well as the common values that 
constitute the substratum of the democratic citizenship in a global context. (Head of State 2009, Preamble)

Nevertheless, Law 3/2006 refers directly to the UNESCO Convention against Discrimination in Education (UNESCO 1960). Further, the Agreement between the Kingdom of Spain and the Kingdom of Morocco (Agreement between the Kingdom of Spain and the Kingdom of Morocco 2007) guarantees the rights of unaccompanied children according to the CRC (Convention on the Rights of the Child 1989).

In Sweden, the discourse on global right holders appears in political documents relating to the incorporation of the CRC in Swedish legislation, as reported by the Children's Rights Commission (SOU 2016, p. 19) and the Government Bill 2017/18: 186 Incorporation of the UN Convention on the Rights of the Child (Regeringens Proposition (2017)). For instance, these documents suggest the incorporation of the CRC in Swedish legislation as a strategy to introduce children's rights perspectives in all decisions and measures relating to asylum-seeking children.

Asylum-seeking children have been recognised for almost twenty years in Swedish foreign legislation. Increased focus on the special vulnerability of asylum-seeking children also exists internationally, through the Convention on the Rights of the Child, and within the EU. To reduce the vulnerability of these children it is of central importance that there is one child rights perspective in the asylum process. This assumes that decision makers, other officials and persons representing children have knowledge of the child's human rights. It is these people's task to ensure that the rights of the child are made visible and respected in all decisions and measures concerning children. (SOU 2016, pp. 19, 149-50) (Author's translation)

This positioning was also adopted by Spain in Law 12/2009 (Head of State 2009), where Article 46 gives special protection to this collective. Spain also promises to provide assistance to unaccompanied Moroccan children inside its national territory and give them the "same protection as for nationals" (Agreement between the Kingdom of Spain and the Kingdom of Morocco 2007, Art. 4). For these children, Spain agrees to provide "the appropriate health and psychological assistance and the qualified assistance they require" (Head of State 2009, Art. 47).

\subsection{Unaccompanied Afghan Minors as Foreign Citizens Transnational Documents}

Transnational documents include unaccompanied Afghan minors as foreign citizens in the EU and the Swedish deportation agreement with Afghanistan that legalized their mass deportation. In the document Joint Way Forward on Migration Issues between Afghanistan and the EU (2016), the EU and Afghanistan agreed to cooperate in and facilitate the deportation of Afghan citizens from EU countries. By stressing "nationals," "territory of the EU," and "facilitate their reintegration in Afghanistan," these documents support the extradition of unaccompanied minors rather than securing their rights in EU countries.

This JWF identifies a series of actions to be taken as a matter of urgency by the EU and the Government of Afghanistan with the objective to establish a rapid, effective and manageable process for a smooth, dignified and orderly return of Afghan nationals who do not fulfil the conditions in force for entry to, presence in, or residence on the territory of the $E U$, and to facilitate their reintegration in Afghanistan in a spirit of cooperation. (Joint Way Forward on Migration Issues between Afghanistan and the EU 2016, Introduction, page 1, authors' italics)

In the case of Moroccan children, the Agreement between Spain and Morocco ( Agreement between the Kingdom of Spain and the Kingdom of Morocco 2007) uses similar expressions and words as the above document. We find the first reference in the sentence in which both countries promise to "establish a joint framework for the prevention of the illegal emigration of unaccompanied minors and the protection and return of said 
minors" (Art. 1). Further, in Article 2 both countries develop a relationship of cooperation to "promote the assisted return of minors to their families or to the institution of guardianship of the country of origin, as well as their social reintegration." These Articles use the same two strategies as Sweden to reinforce the category of foreign citizens: cooperation to facilitate their deportation and reintegration into their countries of origin.

The Memorandum of Understanding between the Government of Sweden and the Government of the Islamic Republic of Afghanistan allows the Swedish government to implement the EU agreement with Afghanistan at the national level. Focusing on the Swedish state's rights in its national territory, this document neglects the rights of unaccompanied Afghan minors to not be deported.

Afghan nationals, who are found not to have legal right to stay in Sweden after their applications are legally processed, protection needs or compelling humanitarian reasons in accordance with Swedish legislation justifying prolongation of their stay in Sweden, could opt for voluntary return according to Swedish law based on the knowledge of the situation in the intended places of their return after a final negative decision on their application to stay in Sweden or on their international protection claim. Afghan nationals, who nevertheless continue to refuse to avail themselves of the option of voluntary return, may be ordered to leave Sweden as an option of last resort. (Memorandum of Understanding between the Government of Sweden and the Government of the Islamic Republic of Afghanistan 2016, Article $3 b$, pages 2-3, authors' italics)

Spain formulates something similar in two documents. First, it promises to provide these children with the assistance they need but creates a distinction between them and nationals using the expression "same protection as for nationals" (Agreement between the Kingdom of Spain and the Kingdom of Morocco 2007, Art. 4). Also, Spain reinforces the category of foreign citizens by granting the Foreigner Identity Card to unaccompanied minors who acquire a residence permit once they reach the age of majority (Ministry of the Presidency 2011, Art. 197). Equally, the creation of a Register of Foreign Unaccompanied Children establishes another gap or differentiation between them and Spanish society ( Ministry of the Presidency 2011, Art. 190).

The citizenship of these groups is used as an argument to limit unaccompanied migrant minors' possibilities of becoming complete rights holders in Sweden and makes the enactment of Article 22 of the CRC difficult. However, both the EU's and Sweden's agreements with Afghanistan stipulate the responsibilities of national authorities to ensure a legal process for the deportation of Afghan nationals to Afghanistan. Also, Spain's claims for the necessity of promoting their "social reinsertion" in Morocco indicate that unaccompanied minors in Spain are excluded from the host society (Agreement between the Kingdom of Spain and the Kingdom of Morocco 2007, Art. 2).

To facilitate reintegration, the EU is developing and funding programs providing support for Afghan nationals returning to Afghanistan. Special consideration will be given to the needs of women, children and other vulnerable groups in the development and implementation of the reintegration programmes. (Joint Way Forward on Migration Issues between Afghanistan and the EU 2016, Part II, page 3, authors' italics)

Likewise, Spain goes further because it is responsible for funding programs in Morocco to "prevent" the migration of these children (Agreement between the Kingdom of Spain and the Kingdom of Morocco 2007, Art. 7). Therefore, Spain accepts an important role in the migratory process, albeit not as a host state. The case of Moroccan children is rather special, in that they can be returned to the Moroccan protection service, which may not be in the children's best interests (Ministry of the Presidency 2011, Art. 192).

In the case of Sweden, the Memorandum of Understanding between the Government of Sweden and the Government of the Islamic Republic of Afghanistan makes intertextual 
references to the 1951 Convention relating to the Status of Refugees and its 1967 New York Protocol and to the International Covenant on Civil and Political Rights.

Furthermore, Article 20 in the Swedish Memorandum points out that this document does not replace other national and European law or other international agreements that both parties are obliged to respect. However, the agreement refers to the possibility that national laws can be obstacles to the implementation of the agreement:

This Memorandum of Understanding does not replace national or European legislation or international commitments to which the parties are bound. The parties shall notify each other of any conflicts arising from this Memorandum of Understanding. (Memorandum of Understanding between the Government of Sweden and the Government of the Islamic Republic of Afghanistan 2016, Article 20, page 9, authors' italics)

Nonetheless, references to Article 22 of the CRC for guaranteeing unaccompanied Afghan minors' rights to asylum are not present in the Memorandum. At the same time, the Agreement between Spain and Morocco (Agreement between the Kingdom of Spain and the Kingdom of Morocco 2007) explicitly refers to the CRC and its Facultative Protocols. On the other hand, other intertexts referring to the right to receive asylum in case of war, violent conflicts, etc., and for children to be protected from all kinds of violence are absent in the Swedish Memorandum and Spain's Law 12/ 2009 (Head of State 2009, Art. 47).

On the other hand, the national laws of both countries stipulate that undocumented foreign minors have the same rights as natives, which includes access to education. In Sweden these minors are not required to attend school, so they can choose whether to receive an education or not, whereas in Spain all children under 16 years old are required to attend school regardless of their legal status (Eurydice 2019). This amounts to unequal treatment of these minors by the Swedish authorities due to their legal status (Bunar 2017).

The discourses on "global right holders" and "foreign citizens" are at times intermixed in the bilateral agreements signed by both countries. The words "return," "reestablishment," "in Afghanistan and Morocco," and "returning of foreign citizens" are combined with a more universal idea of where the "vulnerable" groups are to be protected in relation to "international law" during the deportation process. The question of power is present in the way the description of the child changes from being a human in need of protection to a foreign national citizen, i.e., a citizen who does not belong to the national territory. Focusing only on the deportation process, both the Spanish and the Swedish documents prioritize these countries' rights to deport foreign citizens in relation to asylumseeking refugees. Therefore, when the deportation is decided by the national authorities, the responsibility of Spain and Sweden is limited to protecting these children's groups during the deportation process.

\section{The Negotiation of the CRC from a Sustainable Perspective}

Starting from a child rights-based approach to sustainable development, this contribution underlines and compares the discourses in selected Spanish and Swedish migration and education policies on unaccompanied minors' rights to education and discusses their impact on the enactment of the 2030 Agenda Sustainable Development Goals in both countries.

The analysis of the selected documents shows the co-existence of two different discourses on unaccompanied minors: one being the discourse on unaccompanied minors as global rights holders and the other on unaccompanied minors as foreign citizens. The discourse on unaccompanied minors as global rights holders stipulates that all children without exception have a right to human assistance, education, and appropriate protection against violence. Considering accompanied minors as, first and foremost, children, this discourse contradicts restrictive migration policies affecting children. The discourse on unaccompanied minors as foreign citizens limits the responsibility of Spain and Sweden to only protecting these children during the return process to Morocco and Afghanistan, 
respectively. This discourse legitimizes the negotiation of children's rights by bilateral agreements with countries outside the EU aiming to limit migration to EU countries.

While the global rights holder discourse portrays the unaccompanied minor as someone in need of protection, the foreign citizen discourse portrays these same groups of children as foreign citizens who do not belong to the national territory and are therefore unable to apply for asylum. In addition, this research shows that the discourse on global rights holders is only present in the policy documents relating to the fact that the deportation process should follow international law in order to protect the children.

In line with earlier research (Schiratzki 2013; Thorburn Stern 2019a, 2019b), the analysis of the Spanish and Swedish cases shows that even if the CRC is incorporated into the national legislation, it does not automatically ensure the rights of migrant children when restrictive migration policies are in place. Further, in line with Benhabib (2004a, 2004b) and Morgades Gil (2019), the analysis of the two cases shows that the current restrictive European migration policies highlight the existing dilemma between the right of European democracies to regulate their state territories and refugees' rights to full membership in terms of a democratic voice and territorial residence. This analysis shows that this dilemma is even present in the competition for and, at times, conflict between unaccompanied migrant minors' rights as stipulated in both the CRC and the 2030 Agenda and the rights of national states to limit migration. The analysis also shows the difficulties that EU countries face between respect for the 2030 Agenda, the CRC, and their national sovereignty claims.

By signing the 2030 Agenda, Spain and Sweden have committed to working toward the accomplishment of the global sustainable development goals. As children's rights and sustainable development are mutually reinforcing, negotiations on the rights of unaccompanied Moroccan and Afghan minors in Spain and Sweden reveal the stumbling blocks to accomplishing SGD4. By describing unaccompanied migrant minors as citizens, rather than children, international migration agreements make it possible for the Spanish and Swedish governments to deprioritize other international agreements on refugees' rights, such as the CRC and the 2030 Agenda. This fact is reflected in the way the national regulations of these countries refer to these minors. They often use terms such as "nationals, citizens, foreign nationals, refugees, holders of a residence permit, applicants of asylum," which give a reductionist and exclusively legal portrayal of this group in all socio-educational fields.

At the same time, durable solutions to ensure unaccompanied minors' welfare cannot be limited to the discussion about their right to education in European countries and require both the analysis of other aspects of the minors' lives as well as the reason for their migration to Europe. However, by highlighting the right of education as a central aspect for the welfare of these children, this research offers and discusses concrete examples of negotiations that limit the rights of minors stipulated by both the 2030 Agenda and the Convention on the Rights of the Child. Moreover, this study shows how these negotiations facilitate an uncertain asylum process and legitimize the deportation decisions that can put unaccompanied minors' physical and psychological health at risk.

Focusing on the right to education of accompanied minors, this contribution also shows how the 2030 Agenda Sustainable Development Goals are negotiated when European democracies prioritize their rights to limit migration at the expense of the rights of the child in order to put anti-migration policies in place at a time when radical right-wing parties and movements are advancing in Spain and Sweden.

On the other hand, some of the limitations of this research should be noted. In the first place, the legal framework of both countries is very extensive, which means that presenting all their arguments in a synthesized way has been a complex and difficult task. Likewise, this article is framed within the educational field, but due to the nature of the object of study a degree of solid legal knowledge is required, which as researchers we regard as a limiting factor. In addition, the reality of unaccompanied foreign minors is very varied and is often made invisible by national statistics, so it would be appropriate to address this in the future by means of interviews with these minors and with social workers. 
In future research it will be advisable to examine the European regulations on unaccompanied foreign minors' rights to education. Similarly, it will also be advisable to analyze the intertextuality of European legislation in relation to the 2030 Agenda. It is possible to extend this analysis to other member states, preferably those that have adopted more restrictive measures (such as Hungary and Poland) or have received a greater number of applications (like Germany and Greece).

Finally, this research shows the need to pay attention to the integration of the CRC in the enactment of the 2030 Agenda's goals and targets in order to avoid a simplistic and limited sustainability analysis.

Author Contributions: All the three authors have worked equally in all the steps of the research process: Conceptualization, methodology, software; validation and formal analysis; investigation; resources; data curation; writing - original draft preparation; writing-review and editing, visualization; supervision, project administration; funding acquisition. All authors have read and agreed to the published version of the manuscript.

Funding: This research received no external funding.

Institutional Review Board Statement: Not applicable.

Informed Consent Statement: Not applicable.

Data Availability Statement: Not applicable.

Conflicts of Interest: The authors declare no conflict of interest.

\section{References}

Accem. 2019. Infancia y Adolescencia Migrante no Acompañada. Available online: https://www.accem.es/vulnerables/menoresextranjeros-no-acompanados-mena/ (accessed on 17 October 2020).

Aftonbladet. 2019. Skor Placeras ut-I Solidaritet Mot Utvisningar. Available online: https://www.aftonbladet.se/nyheter/a/ vQXWmw/skor-placeras-ut--i-solidaritet-mot-utvisningar (accessed on 27 September 2019).

Agreement between the Kingdom of Spain and the Kingdom of Morocco. 2007. Agreement between the Kingdom of Spain and the Kingdom of Morocco on Cooperation in the Field of Preventing the Illegal Emigration of Unaccompanied Minors, Their Protection and Their Concerted Return, Signed in Rabat on 6th March 2007. Available online: https://www.boe.es/eli/es/ai/2007/03/06/(1) (accessed on 9 December 2020).

Agreement between the Ministry of Labour. 2019. Migration and Social Security of the Kingdom of Spain and the International Organization for Migration (IOM) to Carry out Projects in the Thematic Areas of Resettlement, Assisted Voluntary Return and Reintegration, Relocation and Integration, Signed in Madrid on 20th August 2019. Available online: https://www.boe.es/eli/es/ ai/2019/08/20/(1) (accessed on 10 December 2020).

Aguaded-Ramírez, Eva María, and Georgia Angelidou. 2017. Menores Extranjeros no Acompañados. Un fenómeno relevante en la sociedad española. La perspectiva de los trabajadores en los centros de acogida. Revista de Educación de la Universidad de Granada 24: 47-63. Available online: http:/ / reugra.es/index.php/reugra/article/view/76 (accessed on 6 January 2021).

Ahrnér, Elisabeth. 2006. Barns Inflytande i Förskolan_Problem eller Möjlighet för de Vuxna? En Studie av ett Utvecklingsarbete och dess Betydelse för att Förändra Pedagogers Förhållningssätt till Barns Initiativ. Licentiatavhandlingar vid Pedagogiska Institutionen. Orebro: Örebro Universitet.

Akkerman, Tjitske. 2012. Comparing Radical Right Parties in Government: Immigration and Integration Policies in Nine Countries (1996-2010). West European Politics 35: 511-29. [CrossRef]

Alemán Bracho, María del Carmen. 2011. Inmigración y servicios sociales. Papers: Revista de Sociología 96: 825-52. [CrossRef]

Andrés Laso, Antonio. 2020. Menores extranjeros no acompañados (mena). Revista jurídica de Castilla y León 50: 7-48. Available online: https:/ / www.jcyl.es/web/jcyl/AdministracionPublica/es/Plantilla100Detalle/1131978346397/_/128492200153 8/Redaccion (accessed on 8 January 2021).

Angelidou, Georgia, and Eva María Aguaded-Ramírez. 2016. Los derechos de los menores extranjeros no acompañados en los centros de menores. Revista Internacional de Didáctica y Organización Escolar 2: 4-20. Available online: http://www.re-doe.com/index. php?journal $=$ reidoe\&page $=$ article\&op $=$ view \&path $\% 5 B \% 5 D=72$ (accessed on 5 January 2021).

Barba del Horno, Mikel. 2019. Los menores marroquíes en Bizkaia, un colectivo en cuarentena social. Inguruak 67: 1-21. Available online: http:/ / www.inguruak.eus/index.php/inguruak/article/view/150 (accessed on 21 January 2019).

Benhabib, Seyla. 2004a. The Rights of Others. Aliens, Residents, and Citizens. Cambridge: Cambridge University Press.

Benhabib, Seyla. 2004b. Jämlikhet och Mångfald. Demokrati och Medborgarskap i en Global Tidsålder. [Original Title: The Claims of Culture, Equality and Diversity in the Global Era]. Göteborg: Daidalos. 
Bray, Mark, Robert Bob Adamson, and Mark Mason. 2007. Introduction. In Comparative Education Research: Approaches and Methods. Edited by Mark Bray, Robert Bo Adamson and Mark Mason. Hong Kong: Comparative Education Research Centre, the University of Hong Kong, 444p.

Bueno Abad, José Ramón, and Francisco José Mestre Luján. 2006. La protección de menores migrantes no acompañados: Un modelo de intervención social. Alternativas. Cuadernos de Trabajo Social 14: 155-70. [CrossRef]

Bunar, Nihad. 2017. Migration and Education in Sweden: Integration of Migrants in the Swedish School Education and Higher Education Systems. NESET II ad hoc Question 3: 1-19. Available online: https:/ / bit.ly/34FiDC6 (accessed on 21 January 2019).

Celikaksoy, Aycan, and Eskil Wadensjö. 2015. Ensamkommande barn i Sverige. Rapport 2015:1. Stockholm: The Stockholm University Linnaeus Centre for Integration Studies (SULCIS), Available online: http:/ / www.su.se/polopoly_fs/1.225235.1424628185! /menu/standard/file/Ensamkommande\%20barn\%20till\%20Sverige\%20\%20rapport\%201.pdf (accessed on 15 January 2021).

Cónsola Párraga, Marc. 2016. La atención socioeducativa de los menores extranjeros no acompañados: Una mirada hacia las expectativas y las necesidades. Educación Social: Revista de Intervención Socioeducativa 64: 44-60. Available online: https: //www.raco.cat/index.php/EducacioSocial/article/view/311853 (accessed on 18 January 2021).

Convention on the Rights of the Child. 1989. United Nations Human Rights Office of the High Commissioner. Available online: https:/ / www.ohchr.org/en/professionalinterest/pages/crc.aspx (accessed on 21 January 2019).

Curriculum for the Compulsory School, Preschool Class and School-Age Educare (Revised 2018). 2011. Stockholm: Skolverket. Available online: https://www.skolverket.se/publikationsserier/styrdokument/2018/curriculum-for-the-compulsory-schoolpreschool-class-and-school-age-educare-revised-2018 (accessed on 27 September 2019).

Curriculum for the Preschool Lpfö. 2018. Available online: https: / / www.skolverket.se/getFile?file=4049 (accessed on 27 September 2019).

Curriculum for the Upper Secondary School. 2013. Available online: https:/ / www.skolverket.se/ getFile?file=2975 (accessed on 27 September 2019).

Dagens Juridik. 2017. Risk för Kaotisk Situation- Lagrådet Sågar Lagförslaget om Nyanlända och Gymnasium. [Risk of a Chaotic Situation- The Council on Legislation Condemns the Bill on New Arrivals and Upper Secondary Schools]. (9 March 2017). Available online: http:/ / www.dagensjuridik.se/2017/03/risk-kaotisk-situation-lagradet-sagar-lagforslaget-om-nyanlandaoch-gymnasium (accessed on 21 January 2019).

Dagens Nyheter. 2018. Unga Väntar i Månader på Beslut om Uppehållstillstånd. [Young People Wait Months for a Decision on Residence Permits] (29 December 2018). Available online: https://www.dn.se/nyheter/politik/unga-vantar-i-manader-pabeslut-om-uppehallstillstand/ (accessed on 21 January 2019).

European Council on Refugees and Exiles [ECRE]. 2017. EU Migration Policy and Returns: Case Study on Afghanistan. Summary and ECRE's Recommendations 2017. Available online: https:/ / reliefweb.int/sites/reliefweb.int/files/resources/Returns-CaseStudy-on-Afghanistan.pdf (accessed on 19 January 2019).

European Council on Refugees and Exiles [ECRE]. 2018. Children in Migration: Collateral Damage? 30th November 2018 News (Editorial: Catherine Woollard, Secretary General for the European Council on Refugees and Exiles (ECRE): 2018). Available online: https:/ / www.ecre.org/children-in-migration-collateral-damage/ (accessed on 22 February 2019).

European Migration Network. 2018. Understanding Migration in the European Union: Insights from the European Migration Network 2008-2018-EMN 10 Year Anniversary Report. (Brussels: European Migration Network, 2018). Available online: https:/ / emnbelgium.be/sites/default/files/publications/00_10_year_anniversary_report_final_en.pdf (accessed on 12 March 2020).

European Parliament and Council of the European Union. 2013. Regulation. (EU) no 604/2013 of the European Parliament and of the Council of 26 June 2013 Establishing the Criteria and Mechanisms for Determining the Member State Responsible for Examining an Application for International Protection Lodged in One of the Member States by a Third-Country National or a Stateless Person (Recast) (OD, L180/31, 2013). Available online: https:/ / eur-lex.europa.eu/legal-content/EN/TXT/?uri=celex\%3A32013R0604 (accessed on 15 January 2021).

Eurostat. 2020a. Newsrelease 71/2020-28 April 2020. Available online: https:/ /ec.europa.eu/eurostat/documents/portlet_file_ entry/2995521/3-28042020-AP-EN.pdf/03c694ba-9a9b-1a50-c9f4-29db665221a8 (accessed on 4 January 2021).

Eurostat. 2020b. Asylum Applicants Considered to be Unaccompanied Minors by Citizenship. Available online: https://ec.europa.eu/ eurostat/web/asylum-and-managed-migration/data/database (accessed on 15 December 2020).

Eurydice. 2019. Integración del Alumnado de Procedencia Migrante. Luxembourg: Oficina de Publicaciones de la Unión Europea, Available online: https:/ / bit.ly/2G85szW (accessed on 24 March 2020).

Fairclough, Norman. 2000. Discourse, social theory and social research: The discourse of welfare reform. Journal of Sociolinguistics 4: 163-95. [CrossRef]

Fairclough, Norman. 2003. Critical discourse analysis as a method in social scientific Research. In Methods of Critical Discourse Analysis. Edited by Ruth Wodak and Michael Meyer. London: Sage Publications, pp. 121-38.

Fernández Peláez, Palmira. 2018. Estado de la cuestión sobre los derechos de los menas en España: Entre la protección y el abandono. RES: Revista de Educación Social 27: 48-70. Available online: https://eduso.net/res/wp-content/uploads/2020/06/menasespa_ res_27.pdf (accessed on 14 February 2020).

Fernández-Ramos, María Victoria. 2019. Niños y niñas no acompañados. Entre la desprotección y la garantía de derechos. Trabajo Social 21: 119-39. [CrossRef] 
Ferreira, Carles. 2019. Vox como representante de la derecha radical en España: Un estudio sobre su ideología. Revista Española de Ciencia Politica, 73-98. [CrossRef]

Figueredo Canosa, Victoria, Pablo Carrasco García, and Adoración Sánchez Ayala. 2017. Estrategias y límites en la inserción sociolaboral con menores extranjeros no acompañados en el marco de los centros de protección: El caso de la provincia de Almería. International Scientific Journal 12: 64-82. [CrossRef]

Flores González, Begoña. 2018. La protección jurídica de los menores inmigrantes no acompañados en España. Revista de Derecho Civil 5: 321-62. Available online: https:/ / www.nreg.es/ojs/index.php/RDC/article/view/281 (accessed on 23 February 2020).

Francia, Guadalupe, and Silvia Edling. 2020. Unaccompanied Afghan minors' rights when restrictive transnational migration policies are in force: The case of Sweden. The International Journal of Children's Rights 28: 894-924. [CrossRef]

García España, Elisa. 2017. Extranjeros sospechosos, condenados y excondenados: Un mosaico de exclusión. Revista Electrónica de Ciencia Penal y Criminología 19: 1-28. Available online: http:/ / criminet.ugr.es/recpc/19/recpc19-15.pdf (accessed on 12 February 2020).

General Courts. 1978. Constitution of 29th December of 1978. Available online: https://www.boe.es/eli/es/c/1978/12/27/(1)/con (accessed on 20 January 2020).

Head of State. 2009. Law 12/2009 of 30th October, Regulating the Right to Asylum and Subsidiary Protection. Available online: https: / / www.boe.es/buscar/act.php?id=BOE-A-2009-17242 (accessed on 11 January 2021).

Hjern, Anders, and Henry Ascher. 2015. Svårt att säkert fastställa ålder hos asylsökande barn. [Hard to safely establish the ages of asylum-seeking children]. Läkartidningen. October 12,41/2015. Available online: https://lakartidningen.se/klinik-ochvetenskap-1/kommentar/2015/10/svart-att-sakert-faststalla-alder-hos-asylsokande-barn/ (accessed on 14 January 2019).

Horcas López, Vicent. 2016. Los menores migrantes no acompañados en España: La construcción jurídica del "diferente". Punto cu Norte 3: 11-40. Available online: http:/ / roderic.uv.es/handle/10550/56830 (accessed on 18 May 2021).

International Covenant on Civil and Political Rights. 1966. United Nations Human Rights. Available online: https://www.ohchr.org/ en/professionalinterest/pages/ccpr.aspx (accessed on 22 February 2019).

Jiménez Álvarez, Mercedes Gema. 2019. Desapariciones de menores extranjeros no acompañados en España: Una primera aproximación a sus significados. Anuario CIDOB de la Inmigración 2019: 168-88. [CrossRef]

Joint Way Forward on Migration Issues between Afghanistan and the EU. 2016. The European Union External Action. Available online: https: / / eeas.europa.eu/headquarters/headquarters-homepage/11107/joint-way-forward-on-migration-issues-betweenafghanistan-and-the-eu_en (accessed on 21 February 2019).

Lag. 2016. Lag om Tillfälliga Begränsningar av Möjligheten att få Uppehållstillstånd i Sverige. [Law (2016: 752) on Temporary Restrictions to the Possibility of Obtaining a Residence Permit in Sweden.]. p. 752. Available online: https://www.riksdagen.se/sv/ dokument-lagar/dokument/svensk-forfattningssamling/lag-2016752-om-tillfalliga-begransningar-av_sfs-2016-752 (accessed on 21 January 2019).

Lainpelto, Katrin. 2019. Ett dömande eller ett fördömande rättsväsende?-En fråga om integration. In Barn, Migration och Integration $i$ en Utmanande Tid. Edited by Helander Karin and Pernilla Leviner. Visby: Rakulga Press, pp. 127-59.

Länsstyrelsen Stockholm. 2016. Lost in Migration A Report on Missing Unaccompanied Minors in Sweden. Report 2016:28. [2016]. Available online: https:/ / www.lansstyrelsen.se/download/18.570d3e071634a145608677/1526069022760/Rapport\%202016-2 8\%20Lost\%20in\%20Migration.pdf (accessed on 21 February 2019).

López Martín, Mónica, Ernesto Gil Garrido, and Cristina Montero Orozco. 2016. El sistema de asilo y su protección social en España. Servicios Sociales y Politica Social 33: 105-15. Available online: https://www.cgtrabajosocial.es/files/5890cf669599c/CEAR_SIST_ DE_ASILO.pdf (accessed on 21 January 2019).

Memorandum of Understanding between the Government of Sweden and the Government of the Islamic Republic of Afghanistan. 2016. On Cooperation in the Field of Migration. Migrationinfo.se. Available online: http:/ /www.migrationsinfo.se/wp-content/ uploads/2016/10/A\%CC\%8Atersa\%CC\%88ndandeavtal-Sv-Afg-signed-16-10-05.pdf (accessed on 21 February 2019).

Mendoza, Karmele, and Iona Belarra. 2017. Menores migrantes en Bizkaia: Entre la protección y el control. RIEM. Revista Internacional de Estudios Migratorios 5: 227-59. [CrossRef]

Meyer, Michel. 2003. Between theory, method, and politics: Positioning of the approaches to CDA. In Methods of Critical Discourse Analysis. Edited by Ruth Wodak and Meyer Michael. London: Sage Publications, pp. 14-31.

Migration Court of Appeal. 2017. MIG 2017:6. UM911-16. 17 March 2017.UAM. Available online: https:/ / www.asylumlawdatabase. eu/en/case-law/sweden-migration-court-appeal-17-march-2017-um-911-16 (accessed on 16 December 2020).

Migrationsinfo.se. 2018. Ensamkommande barn [Unaccompanied children] [2018]. Available online: http://www.migrationsinfo.se/ migration/sverige/asylsokande-i-sverige/ensamkommande-barn/ (accessed on 21 February 2019).

Ministry of Social Affairs. 1989. Order of 13th January 1989 on Refugee Reception Centres. Available online: https:/ /www.boe.es/ buscar/doc.php?id=BOE-A-1989-2449 (accessed on 11 January 2021).

Ministry of the Presidency. 1995. Royal Decree 203/1995 of 10th February, Which Approves the Regulations for the Application of Law 5/1984 of 26th March 26th, Regulating the Right to Asylum and Refugee Status, Modified by Law 9/1994 of 19th May. Available online: https: / / www.boe.es/buscar/doc.php?id=BOE-A-1995-5542 (accessed on 10 January 2021).

Ministry of the Presidency. 2000. Organic Law 4/2000 of 11th January on the Rights and Freedoms of Foreigners in Spain and Their Social Integration. Available online: https:/ / www.boe.es/buscar/act.php?id=BOE-A-2000-544 (accessed on 11 January 2021). 
Ministry of the Presidency. 2007. Royal Decree 240/2007 of February 16th, on the Entry, Free Movement and Residence in Spain of Citizens of the Member States of the European Union and of other States party to the Agreement on the European Economic Area. Available online: https:/ / www.boe.es/buscar/act.php?id=BOE-A-2007-4184 (accessed on 7 January 2021).

Ministry of the Presidency. 2011. Royal Decree 557/2011 of 20th April, Which Approves the Regulation of Organic Law 4/2000, on Rights and Freedoms of Foreigners in Spain and Their Social Integration, after Its Reform by Organic Law 2/2009. Available online: https: / / www.boe.es/buscar/act.php?id=BOE-A-2011-7703 (accessed on 11 January 2021).

Morgades Gil, Silvia. 2019. Un espacio de libre movilidad en Europa ¿Para quién y hasta cuándo? In ¿Una Unión Europea en Crisis? Reflexiones para un Debate Urgente. Edited by Fernando Guirao and Josep Pich. Madrid: Catarata, pp. 119-45.

Nordic Welfare Centre. 2020. Mental Health and Well-Being of Unaccompanied Minors A Nordic Overview. Available online: https://nordicwelfare.org/wp-content/uploads/2020/03/NWC-Ensamkommandes-ha\%CC\%881sa-webb.pdf (accessed on 18 May 2021).

Nu är det Nog. 2018. Vad är det Nog? December 20. Available online: https://www.facebook.com/NUARDETNOG.upprop/posts/ 380097769402051?tn=K-R (accessed on 27 September 2019).

OHCHR United Nations Human Rights Office of the Rights Commissioner. 2020. Children's Rights and the 2030 Agenda for Sustainable Development. Available online: https:/ / ohchr.org/EN/Issues/Children-OHCHR/Pages/2030SDA.aspx (accessed on 27 December 2020).

Open Society Foundation. 2016. Understanding Migration and Asylum in the European Union 2016. Available online: https: / / www.opensocietyfoundations.org/explainers/understanding-migration-and-asylum-european-union (accessed on 14 January 2019).

Prada Belver, Fabriciana Ada, Abadal Villayandre, José María, Huesca Melón, José Manuel, and García Pérez Jesús. 2013. Determinación de la edad ósea en menores extranjeros no acompañados, mediante métodos de imagen. Revista Española de Pediatría Clínica e Investigación 69: 114-19. Available online: https:/ / www.seinap.es/wp-content/uploads/Revista-de-Pediatria/2013/REP\%2069 -2.pdf\#page=51 (accessed on 10 May 2021).

PUCAFREU. 2013. Menores Extranjeros no Acompañados y sin Protección en Europa. Resumen del Informe Comparativo e Informe de la Investigación en España. Available online: https:/ / bit.ly /35GO51Q (accessed on 18 January 2020).

Regeringens Proposition. 2017. Regeringens Proposition 2017/18:186. Inkorporering av FN:s Barnkonvention om Barnets Rättigheter. Available online: https:/ / www.regeringen.se/rattsliga-dokument/proposition/2018/03/prop2.-201718186/ (accessed on 15 January 2021).

Riffaterre, Michael. 1990. Compulsory reader response: The intertextual drive, I Michael, Worton \& Judith, Still. In Intertextuality Theories and Practices. Manchester: Manchester University Press, pp. 56-78.

Rydgren, Jens. 2018a. The Oxford Handbook of the Radical Right. Oxford: Oxford University Press.

Rydgren, Jens. 2018b. The Radical Right: An Introduction. In The Oxford Handbook of the Radical Right. Edited by Jens Rydgren. Oxford handbooks online. Oxford: Oxford University Press.

Rydgren, Jens, and Sara van der Meiden. 2016. Sweden, Now a Country Like All the Others? The Radical Right and The End of Swedish Exceptionalism. Working Paper Series Nr 25. June 2016. Edited by Magnus Nermo, Jens Nydgren and Lotta Stern. Stockholm: Department of Sociology, Stockholm University, Available online: https://su.figshare.com/articles/preprint/Sweden_Now_a_ Country_Like_All_the_Others_The_Radical_Right_and_the_End_of_Swedish_Exceptionalism/14040098 (accessed on 18 May 2021).

Sánchez-Fernández, Sebastían, Yamila Milud-Ahmed, Asma Mohamed-Abdel-lah, Nadia Mohamed-Abdelkader, and Nadia MohamedMohamed Berkan. 2017. Los menores extranjeros no acompañados de Melilla. Análisis de su situación y propuesta de formación socioeducativa. Modulema 1: 121-42. Available online: https://revistaseug.ugr.es/index.php/modulema/article/view/6444/563 4 (accessed on 23 November 2020).

Save the Children. 2018. Protecting Children on the Move. A Guide to Programming for Children Affected by Migration and Displacement. Available online: https:/ / resourcecentre.savethechildren.net/node/13638/pdf/children_on_the_move_programme_ guide.pdf (accessed on 21 January 2019).

Save the Children. 2019. Tankar om att Återvända.Barn, Unga och Vuxna om Återvändande till Afghanistan. Available online: https:/ / resourcecentre.savethechildren.net/sites/default/files/documents/tankar_om_att_atervanda_webb.pdf (accessed on 21 January 2019).

Schiratzki, Johanna. 2013. Välfärdsrätt i Sverige. Juridisk Tidskrift. Vol. 2012/13, nr 4, s. 796-805. Available online: http: / / esh.diva-portal.org / smash / record.jsf?faces-redirect=true\&language=sv\&searchType=SIMPLE\&query=\&af=\%5B $\%$ 5D\&aq= $\% 5 \mathrm{~B} \% 5 \mathrm{~B} \% 5 \mathrm{D} \% 5 \mathrm{D} \& \mathrm{aq}=\% 5 \mathrm{~B} \% 5 \mathrm{~B} \% 5 \mathrm{D} \% 5 \mathrm{D} \& \mathrm{aqe}=\% 5 \mathrm{~B} \% 5 \mathrm{D} \& \mathrm{pid}=\mathrm{diva2} \% 3 \mathrm{~A} 640473 \&$ noOfRows=50\&sortOrder= author_sort_asc\&onlyFullText=false\&sf=all (accessed on 20 May 2019).

Skollag. 2010. Skollag 2010:800 [The School Act] Sveriges Riksdag) Skollag 2010800 [The School Act] 2021 Sveriges Riksdag. Available online: http: / / www.skolverket.se/regelverk/skollagen-och-andralagar (accessed on 28 September 2019).

Solanes Corella, Ángeles. 2016. Un análisis crítico de los centros de internamiento de extranjeros en España: Normativa, realidad y alternativas. Revista Telemática de Filosofía del Derecho 19: 37-76. Available online: http:/ /www.rtfd.es/numero19/02-19.pdf (accessed on 18 November 2020). 
SOU. 2016. SOU 2016:19. Barnkonventionen Blir Svensk Lag 2019) SOU 2016:19. Barnkonventionen Blir Svensk Lag. 2019. Available online: https:/ / www.regeringen.se/contentassets/7bcd0fe8815345aeb2ff0d9678896e11/barnkonventionen-blir-svensk-lag-sou2016_19.pdf (accessed on 26 September 2019).

SverigeDemokraterna. 2018. Paula Bieler-Ny Möjlighet till Uppehållstillstånd. [New Opportunity for a Residence Permit]. Available online: https: / /www.facebook.com/watch/? $\mathrm{v}=1686310211487217$ (accessed on 21 January 2019).

Sveriges Television. 2016. Kritik Mot Skärpt Asyllagstiftning: Bryter Mot Barnkonventionen [Criticism of Stricter Asylum Legislation: Breach of the Convention on the Rights of the Child]. Available online: https://www.svt.se/nyheter/inrikes/kritik-mot-skarptmigrationslagstiftning-bryter-mot-barnkonventionen (accessed on 22 January 2019).

Sveriges Television. 2017a. Barnläkarföreningen om Åldersbedömningar: “Oväntade Resultat". [Paediatric Society on Age Assessments: “Unexpected results".] 3 November 2017. Available online: https:/ / www.svt.se/nyheter/lokalt/smaland/barnlakarforeningenom-aldersbedomningar-hellre-fria-an-falla (accessed on 14 January 2021).

Sveriges Television. 2017b. Sveriges Åldersbedömningar Kritiseras. [Sweden's Age Assessments are Criticized] 27 November 2017. Available online: https:/ / www.svt.se/nyheter/inrikes/sveriges-aldersbedomningar-kritiseras (accessed on 29 October 2020).

Swedish Migration Agency. 2017. Olika Myndigheters Ansvar [Responsibilities of Different Authorities]. Available online: https://www.migrationsverket.se/Andra-aktorer/Kommuner/Om-ensamkommande-barn-och-ungdomar/Olikamyndigheters-ansvar.html (accessed on 21 February 2019).

Swedish Migration Agency. 2019. Det nya Gymnasielaget. [The New upper Secondary School Law]. Available online: https:/ / www.migrationsverket.se/Privatpersoner/Skydd-och-asyl-i-Sverige/Uppehallstillstand-for-gymnasiestudier / Nya-gymnasielagen-1-juli-till-30-september.html (accessed on 13 January 2019).

Swedish Migration Agency. 2021a. The Asylum Process. Available online: https://www.migrationsverket.se/English/Privateindividuals/Protection-and-asylum-in-Sweden/Children-seeking-asylum/Without-parents/Asylum-process.html (accessed on 17 December 2020).

Swedish Migration Agency. 2021b. Children in the Asylum Process. Available online: https://www.migrationsverket.se/English/ Private-individuals / Protection-and-asylum-in-Sweden/Applying-for-asylum/Children-in-the-asylum-process.html (accessed on 19 December 2020).

The Council of Legislation. 2018. Utdrag ur Protokoll vid Sammanträde [Extract from Minutes at Meeting] [28 March 2018]. Available online: https:/ / www.lagradet.se/yttranden/ Ny\%20mojlighet\%20till\%20uppehallstillstand.pdf (accessed on 21 February 2019).

The Guardian. 2017a. 'Sweden Sends Us to Be Killed': Young Afghans Face Perilous Deportation. December 21. Available online: https:/ / www.theguardian.com/world/2017/dec/21/sweden-sends-us-to-be-killed-young-afghans-facing-deportation (accessed on 21 January 2019).

The Guardian. 2017b. Europe Rebuked for Removing Afghans to One of World's Most Dangerous Countries 22 December 2017. Available online: https: / / www.theguardian.com/world/2017/dec/22/europe-rebuked-for-removing-afghans-to-one-of-worldsmost-dangerous-countries (accessed on 21 January 2019).

The National Board of Health and Welfare. 2018. Kunskapscentrum för Ensamkommande Barn Delredovisning [Knowledge Centre for Unaccompanied Children Interim Report 2018]. Available online: https:/ / www.socialstyrelsen.se/Lists / Artikelkatalog/ Attachments / 21000/2018-6-29.pdf (accessed on 21 January 2019).

The Ombudsman for Children in Sweden. 2017a. Ny Anlända Barns Hälsa. Delrapport i Barnombudsmannens Årstema 2017—Barn på Flykt. Available online: https:/ / www.barnombudsmannen.se/barnombudsmannen/i-media/nyheter/20171/psykisk-ohalsavanligaste-halsoproblemet-hos-nyanlanda-barn / (accessed on 5 January 2021).

The Ombudsman for Children in Sweden. 2017b. Röster från Barn och unga på Flykt. Available online: https://www. barnombudsmannen.se/globalassets /dokument-fornedladdning/publikationer/vi_lamnade_allting_och_kom_\protect \ discretionary\{\char \hyphenchar \font\}\{\}\{\}hit_barnombudsmannen_2017.pdf(accessed on 12 January 2021).

The Swedish Paedriatic Society. 2017. Medicinsk Åldersbedömning av Ensamkommande Unga—Nuläge [12 November 2017]. Available online: http: / / www.barnlakarforeningen.se/2017/11/12/medicinsk-aldersbedomning-av-ensamkommande-unga-nulage/ (accessed on 21 January 2019).

The Universal Declaration of Human Rights. 1948. Available online: http:/ /www.un.org/en/universal-declaration-human-rights / (accessed on 21 January 2019).

Thorburn Stern, Rebecca. 2018. Proportionate or Panicky? On Developments in Swedish and Nordic Asylum Law in Light of the 2015 'Refugee Crisis'. In The New Asylum and Transit Countries in Europe during and in the Aftermath of the 2015/2016 Crisis. Edited by Vladislava Stoyanova and Elini Karageorgiou. International Refugee Law Series; Volume 13, Available online: https:/ / brill.com/view/book/edcoll/9789004368293/BP000015.xml (accessed on 20 May 2019).

Thorburn Stern, Rebecca. 2019a. Much Ado about Nothing? The Road to the Incorporation of the UN Convention on the Rights of the Child in Sweden. International Journal of Children's Rights 27: 266-305. [CrossRef]

Thorburn Stern, Rebecca. 2019b. Om barn som migranter och som barn. In Barn, Migration och Integration i en Utmanande Tid. Edited by Karin Helander and Pernilla Leviner. Visby: Rakulga Press, pp. 159-73.

UNESCO. 1960. Convention against Discrimination in Education 1960. Available online: http://portal.unesco.org/en/ev.php-URL_ ID=12949\&URL_DO=DO_TOPIC\&URL_SECTION=201.html (accessed on 7 January 2021).

UNESCO. 2019a. Leading SDG 4-Education 2030. Available online: https:/ / en.unesco.org/themes/education2030-sdg4 (accessed on 7 January 2021). 
UNESCO. 2019b. Right to Education. Available online: https://en.unesco.org/themes/right-to-education (accessed on 25 December 2020).

UNICEF. 2007. A Human Rights-Based Approach to Education for All. A Framework for the Realization of Children's Right to Education and Rights within Education. Available online: https://www.unicef.org/publications/files/A_Human_Rights_ Based_Approach_to_Education_for_All.pdf (accessed on 27 September 2019).

UNICEF. 2018. Children on the Move: Key Facts and Figures. February. Available online: https://data.unicef.org/resources/childrenmove-key-facts-figures / (accessed on 29 December 2020).

UNICEF. 2021. Research Watch. Children on the Move. Available online: https://www.unicef-irc.org/research-watch/Children-onthe-move/ (accessed on 27 December 2020).

United Nations. 2017. Joint general comment No. 3. 2017. of the Committee on the Protection of the Rights of All Migrant Workers and Members of Their Families and No. 22 (2017) of the Committee on the Rights of the Child on the General Principles Regarding the Human Rights of Children in the Context of International Migration. Available online: https://www.refworld.org/docid/ 5a1293a24.html (accessed on 26 September 2019).

Vinaixa i Miquel, Mónica. 2019. La mayoría de edad: Un mal sueño para los menores extranjeros no acompañados. Cuadernos de Derecho Transnacional 11: 571-602. [CrossRef]

Willems, Kurt, and Jonas Vernimmen. 2017. The fundamental human rights to education for refugees: Some legal remarks. European Educational Research Journal 17: 219-32. [CrossRef]

Zillen, Kavot. 2019. Underåriga Unionsmedborgares Rätt till Hälsa i Karin Helander E Pernilla Leviner Barn, Migration och Integration i en Utmanande tid. Visby: Rakulga Press, pp. 45-67. 